As-Syifaa Vol 09 (02) : Hal. 188-194, Desember 2017

ISSN : 2085-4714

\title{
UJI EFEK JUS TAOGE TERHADAP KADAR KOLESTEROL TIKUS (Rattus norvegicus) JANTAN HIPERLIPIDEMIA
}

\author{
Sukmawati, A.Ririn Perawanti Asgap \\ Fakultas Farmasi Universitas Muslim Indonesia, Makassar \\ Email :sukmawati.sukmawati@umi.ac.id
}

\begin{abstract}
The test effect of Taoge Juice on Cholesterol Level of Rat (Rattus norvegicus) Male Hyperlipidemia. This research purpose to know and to fix the concentration of Taoge Juice which have hypolipidemia effect at rat (Rattus norvegicus) male, that administered orally has been conducted. This research used 15 rat male and divided to 5 groups, and each group consist 3 rat male. First group given Na.CMC as control, second group given simvastatin as standard of comparison. The third, fourth and fifth groups given Taoge Juice with $30 \%, 60 \%$, and $90 \%$ respectively. This research done by measuring the normal cholesterol level, induced by propiltiurazil and goat lipid and given by NaCMC, Taoge Juice with 30\%, 60\%, and $90 \%$ concentration and standard of comparison (Simvastatin). This cholesterol level determing by using Human Analyzer. Then do the analyzing data. Besed on analyzed data obtain that control group is significantly $(p<0,05)$ with $30 \%, 60 \%$, dan $90 \%$ group and standard of comparison group. While the group of Taoge Juiceand standard of comparison group not significantly $(p>0,05)$. By analysis of the research result that Taoge Juice have hypolopidemia effect on $30 \%, 60 \%$, dan $90 \%$ concentration.
\end{abstract}

Key words :Hyperlipidemia, taoge juice, cholesterol level, simvastatin

\section{PENDAHULUAN}

Hiperlipidemia merupakan peningkatan lipid yang tersirkulasi termasuk kolesterol dan trigliserida. ${ }^{1}$ Dislipidemia didefinisikan sebagai tingginya kolesterol total (hiperkolesterol), kolesterol low-density lipoprotein (LDL), atau triglycerides serta rendahnya kolesterol highdensity lipoprotein (HDL) ${ }^{2,3}$

Pasien hiperkolesterol, kadar kolesterol total dalam plasma adalah sekitar 7-13 mmol/L (275-500 mg/dL). ${ }^{2}$ Kadar ini meningkat sebanding dengan peningkatan usia, serta memiliki variasi yang besar diantara masing-masing individu. ${ }^{4,5}$

Pada umumnya, masyarakat lebih memilih untuk mengatasi penyakit hiperlipidemia dengan obatobatan kimia. Namun, obat-obatan tersebut masih memiliki kekurangan. Sehingga diperlukan pengobatan alternatif yang berasal dari tanaman 
herbal untuk menurunkan kadar kolesterol. Pengobatan tersebut didasarkan atas pengalaman empiris masyarakat.

Salah satu tanaman yang digunakan sebagai obat tradisional adalah kecambah kacang hijau atau tauge. Tanaman ini dapat diperoleh melalui budidaya sendiri yaitu penanaman kacang hijau pada media air selama 2-3 hari.

$$
\text { Menurut Yasirli }
$$

kandungan saponin dalam taoge efektif menghambat LDL dalam tubuh tanpa mengganggu HDL. Taoge digunakan dalam bentuk jus, karena diketahui bahwa sayuran akan lebih bagus jika dikonsumsi dalam keadaan mentah, dan dalam bentuk jus tauge masih mengandung banyak serat sehingga dapat membantu proses pencernaan dan mempercepat penyerapan nutrisi. ${ }^{6,7}$

Berdasarkan uraian diatas maka telah dilakukan penelitian tentang efek jus taoge dalam menurunkan kadar kolesterol.

\section{METODE PENELITIAN}

\section{JenisPenelitian}

Jenis penelitian yang digunakan yaitu true eksperimental meliputi tiga komponen yaitu kontrol, randomisasi, dan replikasi. Rancangan penelitian yaitu pre-post test control group desain. ${ }^{8}$

\section{Alat dan Bahan}

Alat yang digunakan adalah Human analyzer, restrainer, sentrifuge, dan spoit oral. Sedangkan bahan yang digunakan adalah aquadest, pakan kolesterol, reagen kolesterol, taoge, dantablet simvastatin. Hewan uji yang digunakan adalah tikus putih (Rattus norvegicus) umur 3-4 bulan dengan berat badan 150-200 gram sebanyak 15 ekor.

\section{Prosedur Kerja}

\section{Pembuatan Jus Taoge}

Sampel kecambah yang telah dibersihakan ditimbang sebanyak $30 \mathrm{~g}$ lalu ditambahkan aquadest sebanyak $100 \mathrm{ml}$ dan kemudian dibuat dalam bentuk jus sehingga diperoleh konsentrasi $30 \%$, untuk konsentrasi $60 \%$ dan $90 \%$ ditimbang masingmasing $60 \mathrm{~g}$ dan $90 \mathrm{~g}$ kemudian ditambahkan aquadest sebanyak 100 $\mathrm{ml}$ dan dibuat dalam brntuk jus.

\section{Pembuatan suspensi Na-CMC 1\%}

Sebanyak 1 gram Na.CMC dimasukkan sedikit demi sedikit kedalam $50 \mathrm{ml}$ air air suling panas $\left(70^{\circ} \mathrm{C}\right)$ sambil diaduk dengan menggunakan pengaduk elektrik hingga terbentuk larutan koloidal yang homogen, kemudian dicukupkan 
volumenya hingga $100 \mathrm{ml}$ dengan air suling. ${ }^{9}$

\section{Pembuatan suspensi simvastatin}

Sebanyak $\quad 17,96 \quad \mathrm{mg}$ Simvastatin dimasukkan ke dalam wadah gelas kimia dan disuspensikan dengan NaCMC sebanyak $100 \mathrm{ml}$. Diaduk hingga homogeny dan dimasukkan dalam wadah yang tertutup baik.

\section{Pembuatan Diet tinggi kolesterol}

Diet tinggi kolesterol dibuat dengan cara mencampur sejumlah kolesterol sesuai dengan dosis 200 $\mathrm{mg} / \mathrm{kg}$ BB, kuning telur puyuh 1 $\mathrm{ml} / 200 \mathrm{~g} \mathrm{BB}$, minyak kelapa $10 \%$ selanjutnya ditambahkan aquadest.

\section{Perlakuan terhadap hewan coba}

Tahap pertama tikus diadaptasi selama \pm 7 hari, selanjutnya diukur kadarkolesterolnya sebagai data awal. Setelah itu,masing-masing tikus diiberikan diet tinggi kolesterol dan larutan propiltiourasil (PTU) 1\% selama $\quad 7 \quad$ hari.Pengukuran kadarkolesterol dilakukan pada hari ke-8 setelah penginduksian. Selanjutnya dilakukan randomisasi yakni membagi tikus menjadi lima kelompok. Tahap selanjutnya adalah pengujian bahan uji dengan perlakuan sebagai berikut : kelompok I diberikan NaCMC 1\% sebagai kontrol negatif, kelompok II diberikan simvastatin10 mg sebagai kontrol positif, kelompok III diberi jus taoge $30 \%$, kelompok IV diberi diberi jus taoge $60 \%$, dan kelompok $\mathrm{V}$ diberi diberi jus taoge 90 \%.Semua perlakuan diberikan secara oral dan dilakukan selama 7 hari.Pada akhir penelitian semua tikus diukur kadar kolesterolnya.

\section{Pengukuran kadar kolesterol pada} hewan uji

Pengukuran kadar kolesterol dilakukan dengan cara diambil darah melalui ujung ekor kemudian ditampung dalam tabung efendrof dan disentrifuge. Selanjutnya dilakukan pengukuran kadar dengan alat Human analyzer yaitu menambahkan reagen kolesterol dengan sejumlah sampel serum darah tikus.

\section{Analisis data}

Data yang diperoleh dari hasil pengukuran kadar kolesterol darah dianalisa secara statistik menggunakan program SPSS (Statistical Product and Service Solutions)dan metode one way anova dan dilanjutkan dengan uji lanjutan Post hoc Test LSD. 


\section{HASIL PENELITIAN}

Tabel 1. Hasil rata-rata pengukuran kadarkolesterol tikus selama 14 hari perlakuan

\begin{tabular}{cccc}
\hline \multirow{2}{*}{ Kelompok } & \multicolumn{3}{c}{ Rata-rata Kadar Kolesterol $(\mathbf{m g} / \mathbf{d L}) \pm$ SD } \\
\cline { 2 - 4 } & Hari ke $\mathbf{0}$ & Hari ke 7 & Hari ke 14 \\
\hline Kontrol Negatif & $12,7 \pm 2,5$ & $105,7 \pm 40,1$ & $180,3 \pm 3,1$ \\
Kontrol Positif & $13,0 \pm 3$ & $101,0 \pm 20,7$ & $21,3 \pm 1,5$ \\
Taoge 30\% & $11,3 \pm 0,6$ & $111,0 \pm 19,2$ & $34,7 \pm 2,9$ \\
Taoge 60\% & $28,3 \pm 8,0$ & $88,7 \pm 16,8$ & $27,0 \pm 2,6$ \\
Taoge 90\% & $20 \pm 2,6$ & $85 \pm 25,7$ & $22,7 \pm 2,1$ \\
\hline
\end{tabular}

Tabel 2. Hasil rata-rata persentase penurunan kadar kolesterol darahtikus setelah 7 hari pemberian sediaan uji pada semua kelompok

\begin{tabular}{cc}
\hline Kelompok & Persentase penurunan \\
\hline Kontrol Negatif & $-70,65 \%^{\mathrm{a}}$ \\
Kontrol Positif & $78,88 \%{ }^{\mathrm{b}}$ \\
Taoge $30 \%$ & $68,76 \%$ \\
Taoge $60 \%$ & $69,55 \%$ \\
Taoge $90 \%$ & $73,53 \%$ \\
\hline
\end{tabular}

Data disajikan dalam bentuk Mean

${ }^{\mathrm{a}} \mathrm{P}<0.05$ dengan semua kelompok perlakuan ( $L S D$ test)

${ }^{\mathrm{b}} \mathrm{P}>0.05$ dengan ketiga kelompok sediaan uji (LSD test)

Hasil rata-rata persentase penurunan kadarkolesterol tikus diatas kemudian diplot dalam grafik batang yang dapat dilihat pada gambar 1 .

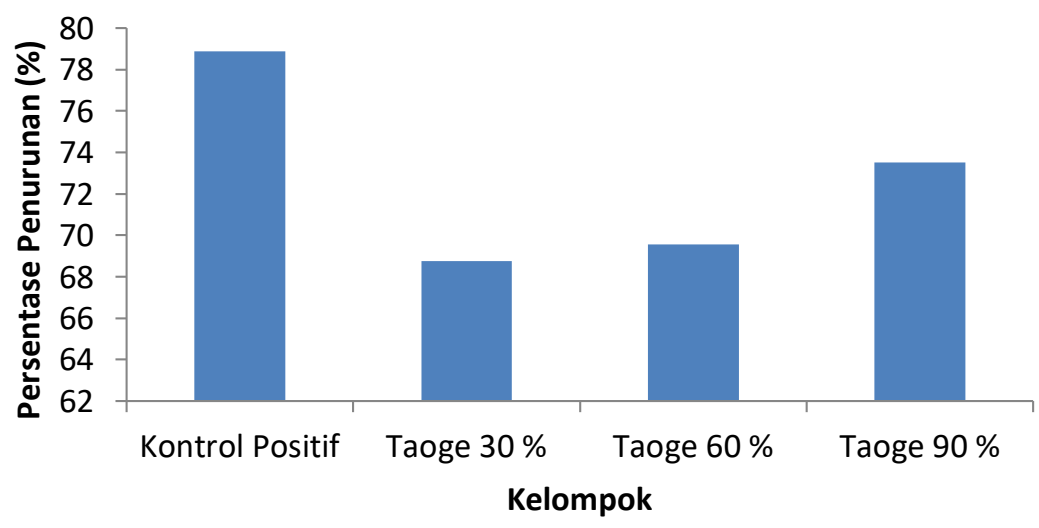

Gambar 1. Grafik rata-rata persentase penurunan kadar kolesterol darah tikus setelah 7 hari pemberian sediaan uji pada semua kelompok 


\section{PEMBAHASAN}

Penelitian ini bertujuan untuk menentukan efek jus taoge terhadap kadar kolesterol tikus putih (Rattus norvegicus) jantan hiperlipidemia. Kondisi hiperlipidemia diperoleh melalui induksi diet tinggi kolesterol dan PTU $1 \%$ selama 7 hari. Pakan tersebut dapat meningkatkan kadar asam lemak dalam plasma yang dapat meningkatkan sekresi VLDL oleh hati ke dalam sirkulasi darah.

Komposisi DTK yang diberikan adalah kolesterol dengan dosis 200 $\mathrm{mg} / \mathrm{kg}$ BB dan kuning telur puyuh 1 $\mathrm{ml} / 200 \mathrm{~g}$ BB. Pemilihan komposisi didasarkan pada penelitian sebelumnya dimana pemberian dosis kolesterol 100 - 300 mg/kgBB dapat menginduksi terjadinya hiperkolesterolemia dan disfungsi endotel. Sedangkan pada penelitian lainnya menunjukkan bahwa pada pemberian pemberian kuning telur $1 \mathrm{cc}$ dapat meningkatkan profil lipid dan penebalan arteri koronaria tikus. ${ }^{10,11}$ Penelitian yang dilakukan oleh Shinnik, et al (1990) dengan menggunakan kolesterol kristal $1 \%$ di dalam diet $18 \mathrm{gr} / \mathrm{ekor} / \mathrm{hari}$ selama 20 hari pada tikus SD, dapat meningkatkan kadar kolesterol tikus. Pemberian pakan tinggi lemak tinggi kolesterol (TLTK) dalam bentuk lemak babi $10 \%$ dan kolesterol murni sebanyak $10 \mathrm{gr} / \mathrm{kg}$ pakan terbukti dapat meningkatkan kadar kolesterol dalam waktu 14 hari. $^{12}$

Tanaman yang diuji adalah taoge yang dibuat dalam bentuk jus. Tanaman ini mengandung saponin yang efektif menghambat LDL dalam tubuh tanpa mengganggu HDL. ${ }^{6}$

Obat sintetik yang diberikan pada kelompok kontrol positif adalah simvastatin, karena obat ini merupakan obat hipolipidemia yang menghambat hidroksi-metilglutril koenzim A (HMG CoA) reduktase yang bekerja dengan menghambat sintesis kolesterol di hati dan akan menurunkan kadar LDL kolesterol plasma yang mengkatalisis tahap awal pembatas laju pada biosintesis kolesterol. $^{13}$

Hasil pengukuran kadar kolesterol fselama 14 hari perlakuan dapat dilihat pada tabel 1. Pada tabel tersebut menunjukkan setelah diinduksi diet tinggi kolesterol semua kelompok mengalami peningkatan kadar kolesterol. Rata-rata semua kadar kolesterol diatas nilai normal. Kadar kolesterol normal tikus adalah $10-54 \mathrm{mg} / \mathrm{dL}$.

Setelah di terapi selama 7 hari berturut-turut kelompok kontrol positif dan 3 kelompok konsentrasi jus taoge 
mengalami penurunan kadar kolesterol tikus hingga batas normal sebesar $78,88 \%$; $68,76 \%$; $69,55 \%$; dan 73,53 $\%$ (Tabel 2 dan gambar 1). Sedangkan kelompok kontrol negatif tetap mengalami peningkatan sebesar $70,65 \%$ (Tabel 2).

Hasil perhitungan persentase penurunan kadar kolesterol setelah terapi 7 hari dianalisa dengan mengunakan metode One Way Anova dan dilanjutkan dengan uji Post Hoc Test LSD. Berdasarkan uji lanjutan antar kelompok didapatkan hasil yaitu untuk kelompok kontrol negatif yang diberikan NaCMC menunjukkan perbedaan nyata $(p<0,05)$ terhadap semua kelompok sediaan dan positif. Hal ini berarti bahwa NaCMC tetap memberikan efek peningkatan kadar kolesterol tikus karena bahan ini bersifat inert dan secara fisiologis tidak memberikan efek yang berarti dalam tubuh (tabel 2).

Hasil analisa statistik kadar kolesterol tikus kelompok kontrol positif dengan pembanding simvastatin menunjukkan hasil yang tidak berbeda nyata $(p>0,05)$ dengan ketiga kelompok variasi konsentrasi jus taoge $30 \%, 60 \%$ dan $90 \%$. Hal ini berarti bahwa jus taoge dengan ketiga konsentrasi tersebut efektif dalam menurunkan kadar kolesterol tikus yang sama efeknya dengan antihiperkolesterol Simvastatin.

Dengan demikian, berdasarkan hasil analisa statistik maka disimpulkan bahwa jus taoge dapat menurunkan kadar kolesterol tikus hiperlipidemia. Ketiga konsentrasi jus taoge dapat menurunkan kadar kolesterol, tetapi dari hasil persentase penurunan jus taoge $90 \%$ yang paling efektif dalam menurunkan kadar kolesterol tikus sebesar 73,53\%.

\section{KESIMPULAN}

Berdasarkan hasil penelitian dan pembahasan disimpulkan bahwa jus taoge dapat menurunkan kadar kolesterol tikus hiperlipidemia. Kombinasi ekstrak etanol daun sambiloto $234 \mathrm{mg} / \mathrm{kgBB}$ dengan akarbose 2,05 mg/kgBB yang efektif dalam menurunkan kadar glukosa darah tikus terinduksi aloksan.

\section{DAFTAR PUSTAKA}

1. Sánchez-Aranguren LC, Prada CE, Riaño-Medina C. E, Lopez M. Endothelial Dysfunction and Preeclampsia: Role of Oxidative Stress. Frontiers in Physiology 2014;5:372.

2. Dipiro JT, Talbert RL, Yee GC., Matzke GR, Wells BG, Posey LM. Pharmacotherapy

Pathophysiologic Approach, 8 th Edition. United States of America: The McGraw-Hill Companies Inc. Chapter 28; 2011. 
3. Steyers, Curtis M, Miller F. Endothelial Dysfunction in Chronic Inflammatory Diseases. International Journal of Molecular Sciences 2014;15(7):11324-11349.

4. Mayes PA, Botham KM. Lipids of Physiologic Significance. In : Murray, RK., Granner, DK., Mayes, PA., and Rodwell, VW. : Harper's illustrated biochemistry, $26^{\text {th }}$ ed. New York: Mac Graw Hill; 2003.

5. Barrett KE, Barman SM, Boitano S, Brooks HL. Ganong's Review of Medical Physiology, Twenty-Third Edition. United State: The McGrawHill Companies Inc.; 2010.

6. Amri, Yasirli. Segudang Manfaat Tauge bagi Tubuh (online). Diakses pada 15 Desember 2012.

7. Ummu. 2011. Kecambah Kacang Hijau Punya Nilai Gizi Tinggi. The Epoch Times. (online). (http://diabetes.com) Diakses 5 April 2013.

8. Zainuddin M. Metodologi Penelitian: Kefarmasiaan dan Kesehatan. Surabaya: Airlangga University Press;2011.
9. Parrot EL. Pharmaceutical Technology Fundamental Pharmaceutics. Minnepolis: BurgessPublishing Company;1979.

10. Mufidah. Aktivitas Antiaterosklerosis Ekstrak Terstandar Klika Ongkea (Mezzetia parviflora becc.) pada Tikus Wistar yang Diberi Asupan Kolesterol (Desertasi) Makassar : Universitas Hasanuddin,; 2011.

11. Mustofa $S$, Anindito $A A$, Pratiwi $A$, A Putri A, Maulana $M$. The influence of Piper retrofractum Vahl (Java's chili) extract towards lipid profile and histology of rats coronary artery with high-fat die. Jurnal Kedokteran 2014;4(7):52-59.

12.Sulistyowati, Yeny Pengaruh Pemberian Likopen Terhadap Status Antioksidan (Vitamin C, Vitamin E dan Gluthathion Peroksidase) Tikus (Rattus norvegicus galur Sprague Dawley) Hiperkolesterolemik Semarang :

(Tesis). Diponegoro; 2006.

13. Gunawan G, Sulistia. Farmakologi dan Terapi Edisi V. Jakarta: UI Press.; 2007. 